\title{
TEACHING INFORMATION SYSTEMS WITH A PROJECT ORIENTED COURSE - A CASE STUDY
}

\author{
J. Bekker \\ Department of Industrial Engineering \\ University of Stellenbosch, South Africa \\ jb2@sun.ac.za
}

\begin{abstract}
Many engineering students often find a course in less analytical subjects like Information Systems difficult due to the significant proportion of abstract concepts covered. To help the students understand them requires a teaching strategy other than the conventional. This paper discusses the use of a project-oriented course to overcome many of the difficulties of teaching Information Systems to industrial engineering students. In contrast with the usual approach to projects, where each group of students delivers an independent solution, the teaching approach discussed requires that the given class deliver a single, integrated solution.
\end{abstract}

\section{OPSOMMING}

Baie ingenieurstudente vind ' $n$ kursus met ' $n$ beduidende nie-analitiese komponent moeilik as gevolg van abstrakte konsepte wat behandel word. Die vakgebied van Inligtingstelsels is ' $n$ voorbeeld hiervan. ' $n$ Onderrigstrategie anders as die konvensionele is nodig om studente te help met die begripsproses. Hierdie artikel bespreek die gebruik van ' $n$ projekgebaseerde kursus om sommige van die onderrigprobleme wat ontstaan wanneer Inligtingstelsels aan bedryfsingenieurstudente doseer word, te oorkom. Die onderrigbenadering wat hier bespreek word, vereis dat ' $n$ gegewe klas 'n enkele, geïntegreerde oplossing lewer, in teenstelling met die gewone benadering tot projekte waar studente in groepe werk en 'n onafhanklike oplossing per groep lewer. 


\section{INTRODUCTION}

Information and information systems have become major resources in today's enterprises and must therefore be managed with the same care as other valuable assets such as people, materials, machinery and finances. Although engineers in all engineering disciplines create, utilise and manage information, the industrial engineer, as a manager of resources, should be primarily involved in managing the information resource of the enterprise. A module covering the subject of Information Systems has therefore become an integral part of many industrial engineering programmes.

Engineering students, and particularly undergraduate students, are fundamentally analytically oriented (or formula-thinking), as is the engineering course content in general. This often poses an educational problem when the student is exposed to the soft sciences, for example Industrial Psychology, and in particular Information Systems, since the latter is a broad field which addresses many non-mathematical issues, for example Systems Analysis and Design. While the students initially expect a computer course (judging by the name), they are confronted with and/or surprised by topics like organisational structures, quality assurance through software engineering, and planning for design sessions, to name a few. It has been experienced that students have difficulty in grasping many of the abstract components, for example, the need for and execution of Joint Application Design (JAD).

The result is that the students develop an antagonism towards these topics, especially when being evaluated on them, as they are perceived as vague (and unscientific). Students then acquire a negative perception of Information Systems as a subject and it is argued that this cannot be afforded, as the whole field of information and related technologies has become very important in industrial engineering [1]. Furthermore, the industrial engineer is often involved with integration, for which the information system is a strong driver as well as an enabling technology. A course in Information Systems should therefore offer an opportunity for the engineering student to apply among other things, the information integration principle.

This paper discusses the use of a group project in engineering education. It is based mainly on the principles of collaborative (or co-operative) learning, but includes the requirement of one single result produced by the whole class of students via integration. The following are addressed:

- learning strategies and models

- the course structure

- the group project and its objectives, deployment, execution strategy and deliverables

- student evaluation

- future enhancements

\section{LEARNING STRATEGIES AND LEARNING MODELS}

To address the requirements discussed above, some of the learning strategies followed by students were considered to find an efficient teaching method for a subject with the particular characteristics mentioned earlier. There are several learning strategies; some specific examples are [2]: 
1. Drill and practice

2. Learning by example

3. Learning by analogy

4. Discovery and hypothesis testing

5. Spatial problem solving

6. Mental simulations

7. Tutoring

8. Active learning [3]

At a higher level, three models of learning have been identified. These, are [4]:

1. The objectivist model of learning

2. The collaborative/co-operative model of learning

3. The constructivist model of learning

The objectivist model is the traditional and often preferred one. The lecturer selects, filters, interprets and conveys learning material while passive students are supposed to absorb and reproduce the knowledge on demand [5]. The constructivist model is an alternative to the objectivist model, and it stresses the relationship between what is known and what are new experiences and knowledge discoveries. The collaborative model of learning is obtained when social interaction and the constructivist model are combined [5].

Students of the current era are Millenials, i.e. they belong to the "Millenial Generation". Members of this generation require a holistic learning approach since they grew up in a different social environment to their Generation $X$ lecturers [6], hence new learning approaches are required. Co-operative learning is a widely accepted (modern) learning model with many advantages to the students $[7,8]$ and was thus considered for the new course design.

Given the above and considering the specific demands of the course, a new course structure and learning approach could be formulated for the module in Information Systems. These are subsequently discussed.

\section{THE REVISED COURSE STRUCTURE}

The original Information Systems course was presented to final year industrial engineering students over a period of 14 weeks (one semester), with a semester test midway, usually in week 7, while the final examination followed in week 14. The basis of the course was Systems Analysis and Design, which primarily focused on the development of a relational database management system (RDBMS). This was mainly taught in a passive mode (objectivist model) - the student received lectures, where one or two chapters in the textbook were covered per lecture, while a tutorial on a different day was supposed to test the student's comprehension of the concepts. This was mainly a drill-and-practice session where exercises were done from the textbook and the results compared to model solutions.

This teaching method was considered to be inadequate for the following reasons: 
- There was no real practical experience for the students

- In this particular field of study some problems with a practical basis still appear like academically formulated ones. The students therefore do not believe that they are capable of addressing practical problems.

The continuous growth of and advances in the information era called for an assessment of the current course content and teaching approach to determine shortcomings. The course would need to be restructured with new material introduced to make it more relevant and to address current needs. The delivery and presentation of the course as well as students' involvement and participation should also be enhanced. The following factors were major drivers:

- Students should develop an appreciation of the Internet from a business point of view and get exposure to related technologies.

- Students should experience the real world (at least partially). This would comprise simulation of practice via involvement with teamwork, communication, working independently and within tight schedules, and to hold efficient meetings.

- Students should understand that information is the integrator of the enterprise.

- An opportunity is required where students could apply the Information Systems course theory before going into practice.

- The course should support the fundamental philosophy that the industrial engineer is an integrator of technologies, people, machines and other resources.

The Information Systems course was subsequently restructured to involve the students in several aspects of the Information System domain, and to accommodate all the factors mentioned above. It was divided into two parts: the first part consisted of formal lectures with tutorials, as in the original course, while the second part involved a project with exposure to various technologies and shaped by the factors listed above. The semester test was still taken during week 7, while the examination in week 14 included questions on the project. The objectivist model would be used mainly in the first half of the semester, where knowledge is transferred from the lecturer to students, with drill and practice, learning by example and tutoring to support the process. The past successes using a group project in the education process $[9,10,11]$ inspired a similar approach, and led to formulation of the project mentioned above. It was assumed that the group setting would benefit students, as knowledge is socially constructed [12].

The following figure shows the original and revised course structures:

Original structure

\begin{tabular}{|c|c|c|c|}
\hline $\begin{array}{c}\text { Lectures and tutorials } \\
6 \text { weeks }\end{array}$ & $\begin{array}{c}\text { Semester } \\
\text { Test }\end{array}$ & $\begin{array}{c}\text { Lectures and tutorials } \\
6 \text { weeks }\end{array}$ & $\begin{array}{c}\text { Final } \\
\text { exam }\end{array}$ \\
\hline
\end{tabular}

Revised structure

\begin{tabular}{|c|c|c|l|}
\hline $\begin{array}{c}\text { Lectures and tutorials } \\
6 \text { weeks }\end{array}$ & $\begin{array}{c}\text { Semester } \\
\text { Test }\end{array}$ & $\begin{array}{c}\text { Project and supporting } \\
\text { lectures } \\
\mathbf{6} \text { weeks }\end{array}$ & Final exam \\
\hline
\end{tabular}

Figure 1: Comparison of the original and revised course structures 
The difference between the two structures is in the second half of the semester where the project was introduced. The lectures during this period comprised hands-on introductory training sessions using the various software packages required for the project. These training sessions were specifically based on the learn-by-example strategy, while pointers were provided to the students for further investigation, thus stimulating learning through discovery. All formal contact sessions were, however, terminated after three weeks (six training sessions) to allow more time for the project work. The collaborative and constructivist models of learning were required for the project-based phase, where students had to interact, share and discover knowledge. The group project will now be discussed in greater detail.

\section{DESCRIPTION OF THE GROUP PROJECT}

The project was based on a traditional manufacturing enterprise comprising the major resources of people, machines, material and money while the information system had to be internet-based. The components or divisions of the enterprise are shown in Figure 2.

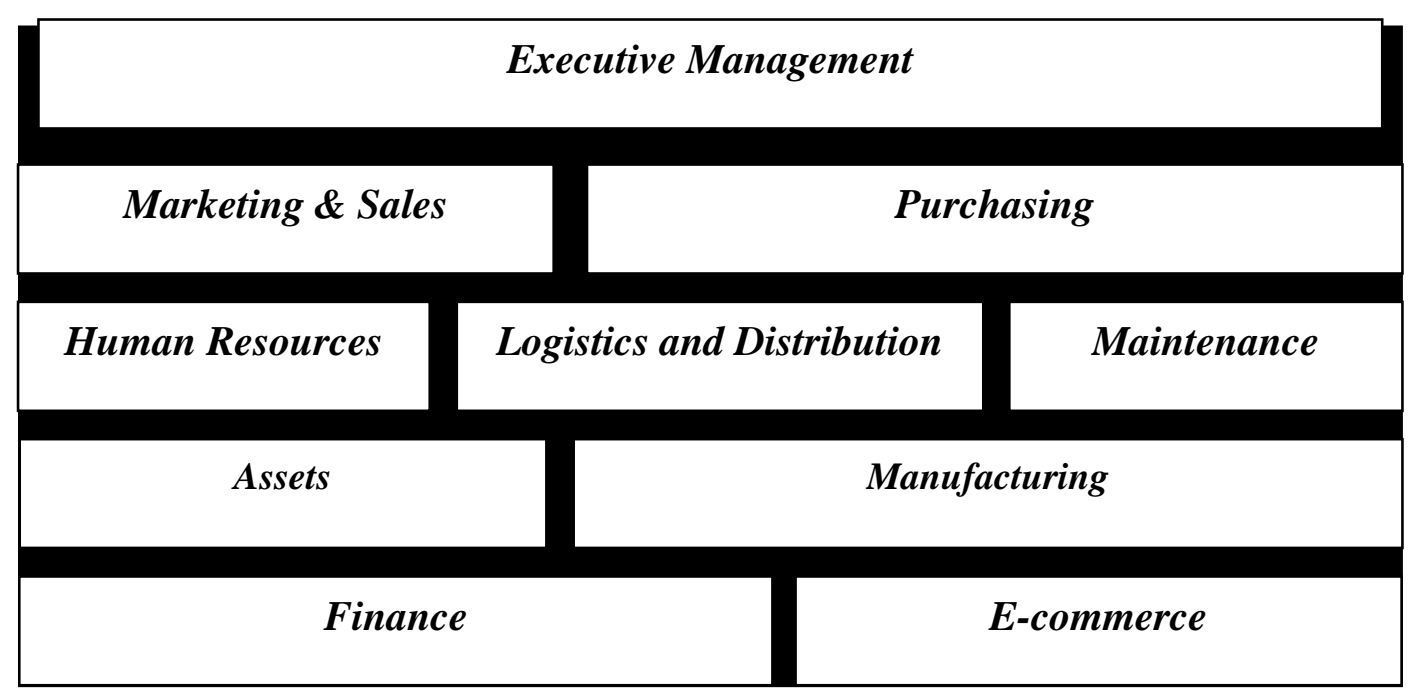

Figure 2: Building blocks of the enterprise

The divisions form the building blocks of the enterprise, while the information system is the cement bonding them together. The building blocks were described in detail to the students, and a brief summary of each is given below:

\section{- Financial division}

The financial division has several accounts, these are

- $\quad$ Budgets

- $\quad$ Salaries

- $\quad$ Materials

- $\quad$ Sales revenue

- $\quad$ Taxes

These accounts are used for managing expenses and income. 


\section{- Human resources}

The company employs people with various levels of skills, i.e. temporary staff, artisans, graduates. These employees must appear on the payroll, and basic aspects of human resource management must be addressed, for example salaries and leave.

\section{- Marketing and sales}

A reference list of customers is required, where customer detail is recorded, e.g. the geographical location of a customer. This in turn necessitates a regional mapping of the world. Sales forecasts are required, based on past sales figures. It must also be possible to extract information on the efficiency of the marketing effort, i.e. how much was spent during a given period on a certain customer in a specific location.

\section{- Assets}

A complete database of assets of the enterprise (tangibles) must be maintained. Assets include fixed assets like machines, while consumables such as raw materials and finished products are considered as moving assets. This database is typically updated when a purchase is made or equipment is phased out.

\section{- Purchasing}

This division acquires raw materials for production, infrastructure equipment (desks, computers, chairs etc.), tools and machines. It should also maintain an inventory of assets, which is updated when equipment is received or discarded. Employees that require one or more items complete requisitions, and each division has one or more person(s) responsible for entering requisitions from that division.

\section{- Maintenance}

A team of multi-skilled technicians, who must ensure the availability of the machines to support the manufacturing function, maintains the machines. Records of failures, maintenance tasks, operators, technicians, spare parts and so on must be kept.

\section{- Manufacturing}

The manufacturing division uses several lathes, milling machines, injection-moulding machines, presses and drills. Products are manufactured by using some of the machines in sequence. Employees working in this division may include machine operators and maintenance technicians. Machines may fail, which will require resources from the maintenance function.

\section{- E-commerce}

The company sells products over the counter, but also does electronic business. A subsystem supporting e-commerce is therefore required. Customers may browse through products and order on-line. Bank credit verification is excluded from the project.

\section{- Logistics and distribution}

This division distributes orders via predetermined routes. Order tracking is required while split orders are allowed.

\section{- Executive management}

Some form of information aggregation is required to realise an executive information 
system. Various queries of the data structure were required for this purpose, for example:

- Materials costs per period

- Personnel turnover

- Maintenance costs per period

- Sales revenue per period

- Salary costs per period

- List of assets and depreciated capital value of assets

The intention was not to require a perfect information system for this enterprise, but to use its requirements as a vehicle to improve teaching since e.g. co-operative learning is required. Specific business events were given to each division (e.g. "An order is placed", "A machine fails") in order to reduce the complexity of the information system and to help students with scoping the project. There were 10 divisions, which required nine groups of students, since all groups would develop the executive management division (each group had to supply aggregated management information from their group).

\section{OBJECTIVES OF THE PROJECT}

The project had several objectives, which were as follows:

- For the students to apply the theory of Systems Analysis and Design to develop an information system as a product, serving the major needs of the enterprise described above.

- For the students to demonstrate the ability to integrate the sub-components of a system in order to deliver a working whole.

- The project aimed to simulate practice and working in teams, in terms of the following:

- intra-disciplinary teams ("colleagues"), which means that they had to work as a group and therefore practise teamwork

- interdisciplinary teams ("others"), which means groups had to communicate across group boundaries, because there were shared entities and business processes in the information system and these could not be designed in isolation. This requirement also supported the integration principle

- To expose the students to the latest technology in the rapidly developing information technology arena.

- For the students to practise communication skills, as communication was required within groups, but also across the group boundaries.

- To create business information awareness in the students.

- To maintain the students' interest and enthusiasm.

- To develop experience in the abstract components of the course, some of which are:

- Joint Application Design (JAD)

- $\quad$ Rapid Application Development (RAD)

- $\quad$ Some "user" involvement (Lecturer)

- Appreciation for organisational design and its relation to the information system

Although the principle of project-based education is not new [9, 10, 11], an important requirement here was that the various group efforts had to be integrated into a single working entity, which added new dimensions to the learning process. It also increased the students' 
dedication, since no group wanted to be the weakest link in terms of the final product. To be successful in the project, the groups had to carefully design their part of the system and identify interfaces with other groups. These interfaces include information processes and data sharing.

\section{PROJECT DEPLOYMENT}

The project followed the steps below:

1. Grouping the students:

Groups of students had to be formed to support the education approach as outlined above, and each group had to be assigned to a division of the enterprise (see Figure 2). From this figure it also follows that the number of groups is implied, while each group should consist of three to four students [13], or four to five students [14]. This causes a problem, because the number of students in a class usually cannot be divided into groups of equal size. At least one group then has one member less than the others, which makes the students in that group feel that they have to work harder. This approach can therefore be followed only where classes are large enough to allow for groups of four to five students each, i.e. 36 to 45 students per class. The group size must always be proportional to the workload, i.e. a fair load per student should prevail in accordance with the course outcomes.

2. The next consideration was how to form the groups, considering that group composition can have effects on learning [13]. Different grouping strategies can be followed, but grouping is often difficult and/or controversial, and several methods have been suggested in the past [9]. Natural selection is the first possibility, but undesirable circumstances may occur when students are allowed to form their own groups [9]. Students may tend to form groups based on status, academic ability, ethnicity or gender, while groups should be diverse in ability [7]. It was observed that many students were unhappy with their placement when the lecturer assigned them to a group because they did not end up with friends. Students also have different schedules, which make it difficult to find times for their project meetings.

Group assignment however supports the practical experience of many, i.e. where one cannot (always) select one's colleagues, and where one has to work with people who have different values and cultures and are from the opposite gender. [7] and [15] support this view. Also, students should be prepared for the workplace in senior years instead of being protected [7]. It was therefore decided to assign members to groups instead of allowing natural selection. Since the students had to deliver a complete, single product, which would only work properly if its parts were functioning correctly, each group should at least have the same potential. The demands per group were designed so that the workload and challenges were more or less the same. This also ensured fairness towards the students.

The following method for group forming was developed: 
- Step 1: The members of the class were sorted in descending order based on a sort parameter. The sorting parameter used was their overall performance in the Information Systems course up to and including the semester test. The top students on the list were each randomly assigned to a group. These names are ordered in columns, each column representing a group. Their names were then removed from the list. The students at the top of the new list were again each randomly assigned to a group, and the names were put under the first row of names. These names were then removed from the class list, and the process continued until the list was exhausted.

- Step 2: Since each student had an associated rating (which was used in Step 1), the average rating of each group could be determined. Groups with extreme ratings (high or low) were identified and names were exchanged on the same level between groups. After each exchange, the average group rating was recalculated. This process was continued until the average group ratings were approximately the same.

A possible limitation of this method was that only the students' marks were used to classify them, but lack of time prevents more detail student analysis, e.g. personality profiles. A study [16] has shown that engineers need many other qualities apart from academic performance to be effective.

3. Handing out project description and requirements:

A user requirement document outlining the business and its processes was provided to the students. Some information was deliberately omitted, as specifications are hardly complete in practice, and engineers must develop the ability to identify the lack of information, then obtain it. Major project milestones were provided to keep the academic exercise on schedule, but students could otherwise schedule tasks as they wished.

4. Exposing the students to the applicable technology:

Apart from the theory of Systems Analysis and Design, supplementary knowledge had to be acquired in order to execute the project. This included knowledge of a relational database management system, a web authorisation tool as well as a web programming language. These were of secondary importance, since the objectives of the course were to teach and practice principles, not proficiency in the use of certain software products.

\section{PROJECT EXECUTION STRATEGY}

Each group represented a "company" which had to design one building block of the given organisation's information system, with the goal of integrating each building block into a single system. Data- and process models had to be developed, which required extensive communication among groups, as it was necessary to share common attributes of data submodels among different groups, as well as some data flow processes. The students experienced and extensively applied the principles of Joint Application Design (JAD) using the lecturer as the client. The steps in the systems development life cycle $[17,18]$ were followed, which required application and understanding of the theory. 
The data models were implemented in Microsoft ${ }^{\circledR}$ Access and the web pages (forms, interfaces etc.) were developed with Microsoft ${ }^{\circledR}$ FrontPage. The proposed information system's data flow processes and software code was implemented by Active Server Pages (ASP) code, which the students had to program. Again inter-group communication and collaboration were required to integrate the different building blocks. Since the business processes were not specified in detail, a further challenge was left to the students to design, develop and implement these. A typical design of the data model is shown in Figure 3; the final design had to be agreed upon before the groups could proceed with other activities.

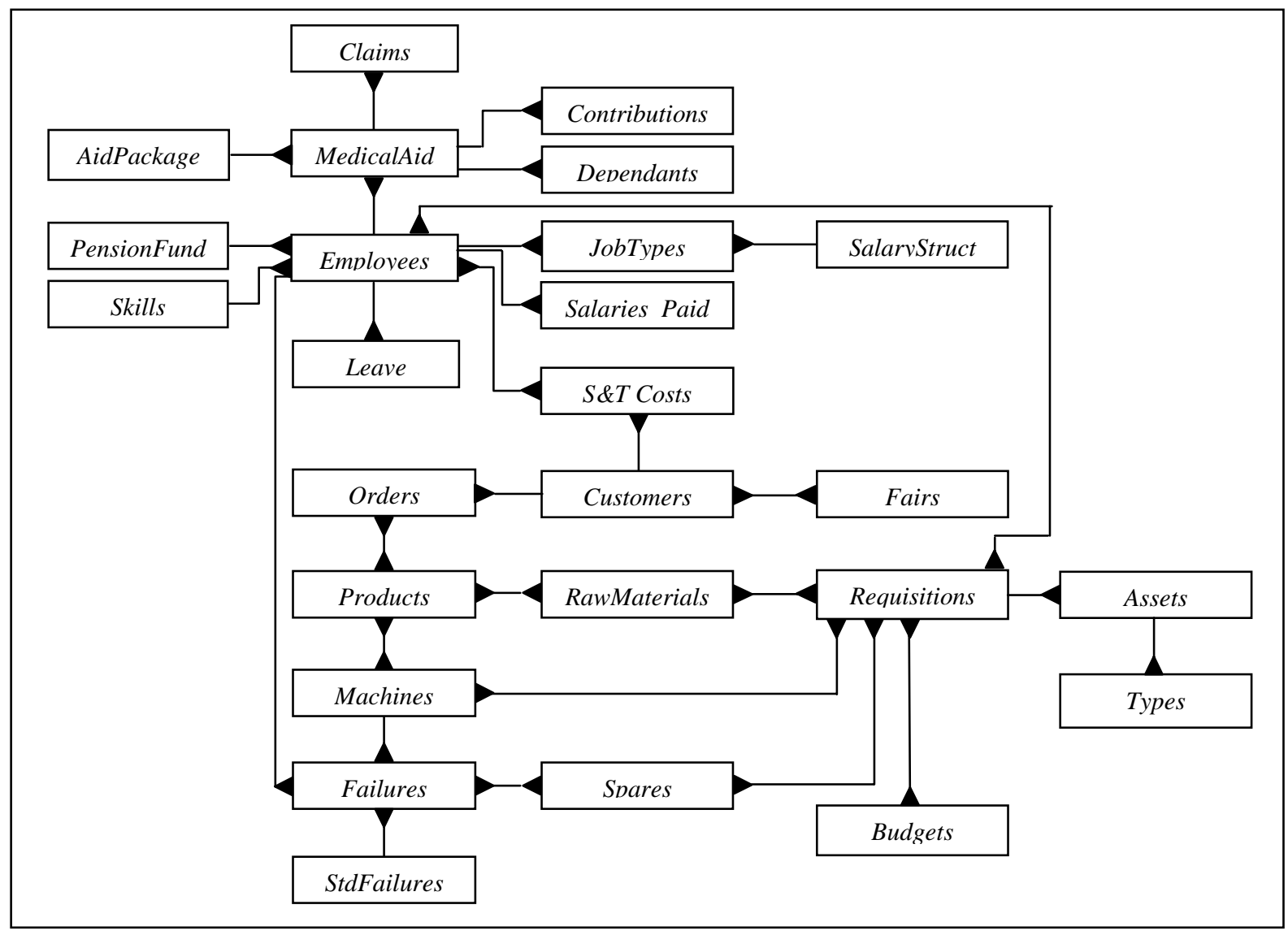

Figure 3: Typical data model of the enterprise (entity-relationship diagram)

\section{PROJECT DELIVERABLES}

The following were the deliverables for the project:

- A working basic information system with a web interface.

- A presentation by each group, explaining how its subsystem worked, and a demonstration to the lecturer and the rest of the class.

- A design report, which had to include the following:

- project objectives (for each subdivision)

- project plan

- detailed description of the design, including quality assurance through software engineering 
- $\quad$ outline of the total structure with an indication of where the group's subsystem fitted into the overall information system

- explanation of the steps followed in the design process

- list of assumptions

- $\quad$ what was learned from this project

- feedback and suggestions

Not all the elements of a typical information system were required in the final product due to time constraints. Elements excluded were user training, complete data validation and programmed security. The students are made aware of these elements through the course material.

\section{ASSESSMENT}

The students were assessed on three main aspects:

\begin{tabular}{|l|c|}
\hline Topic & Weight (\%) \\
\hline 1. The project presentation & $68 \%$ \\
2. The capability and functionality of the information system & \\
\hline 3. Report & $8 \%$ \\
$\quad$ Neatness, professionalism etc. & $24 \%$ \\
$\quad$ Design process documentation & \\
\hline
\end{tabular}

Table 1: Evaluation categories

The mark obtained per group was adjusted using a peer rating that penalizes the passengers (students that are not participating) that were potentially present in the various groups. This is accepted practice when applying co-operative learning and there are some indicators available for doing it [19]. A simple, self-invented approach was followed in this course. Group members provide their names in a table in the group's report, with a rating (individual percentage effort) next to the name. Each student signs next to his/her name. The project mark is then adjusted for each individual. Suppose a group consists of four members, and the ratings are $40 \%, 30 \%, 15 \%, 15 \%$, then the first two students would receive higher marks, while the last two students would receive lower marks. Since students submitted varying ratings, it can be concluded that they were generally not polite towards passengers in the groups. Questions on the project form a substantial part of the final exam paper, which further penalizes passengers.

Students need not explain the method of how the rating was determined. Also, no directions were given to them of how to do it, because they should get used to developing their own evaluation standards on diverse matters. Oakley et al [7] suggest the opposite. Current research by the author considers new buddy rating systems and procedures to adjust marks according to the ratings.

\section{EXISTING SHORTCOMINGS AND FUTURE ENHANCEMENTS}

Improving teaching and learning should occur incrementally and holistically [6]. The approach described is certainly not perfect, and further enhancements can be made. Currently, 
students are lacking some abilities while working on the project, e.g. how to deal with conflict and passengers in groups. Although the students have a problem-solving background when they reach the final year of study, they should be briefed on problem solving in practical situations using existing literature [20]. Topics like leadership and teamwork are treated in other modules and should be revised when deploying the project.

\section{CONCLUSIONS}

This educational approach has been applied over several years and its success can be deduced from the qualitative feedback from students. Negative student feedback was directed towards the time demanded by the project, while positive feedback indicated that the project allowed for application of the theory under supervision, and thus a better understanding of it. Students generally found the collaborative learning approach effective. A continuous improvement process of this approach should further benefit the students' learning experience. This includes reinforcement of knowledge on leadership, teamwork and problem solving.

Academics at tertiary institutions should be aware of changing educational needs due to technological advances, and also of the different generation types that require education. New teaching- and learning methods should be continuously researched and carefully implemented.

\section{SUMMARY}

In this paper, a project was discussed as a support for education in a course with diverse requirements. The project design as described was intended to simulate practice, as it required good communication and co-operation in teamwork. Information system design principles were applied, integration being a key issue.

The concept of group projects proved, once again, to be of great educational value, and it has been shown that it can be extended by a requirement for a single, integrated result. This adds new dimensions to the education process since it forces students to think beyond the boundaries of their isolated task, and to identify and develop interfaces with other design teams while creating a real result.

\section{REFERENCES}

[1] Mitel, A. (Editor-in-chief). March 1998. International Journal of Industrial Engineering.

[2] Eberts, R.E. 1986. 'Learning Strategies in CAI design', International Journal of Engineering Education, 2(1), pp. 51-59 .

[3] Felder, R.M. and Brent, R. 2003. 'Learning by Doing', Chemical Engineering Education, 37(4), pp. 282 - 283.

[4] Li, H. 1997. 'Viewpoint: Using Information Technology to Enhance Engineering Education’, International Journal of Engineering Education, 2(1), pp. 319-324.

[5] Nuldén, U. 1997. 'Designing Environments for Reflection and Collaborative Learning', The $9^{\text {th }}$ Annual Convention and Conference of Australasian Association for Engineering Education, Ballarat, Victoria, Australia, 14 - 17 December 1997, pp. 325 - 329. 
[6] Poindexter, S. 2003. 'The case for holistic learning', Change, 35(1), Jan-Feb 2003, pp. $24-30$.

[7] Oakley, B., Felder, R.M., Brent, R. and Elhajj, I. 2004. 'Turning Student Groups into Effective Teams', Journal of Student Centered Learning, 2(1), pp. 9 - 34.

[8] Haller, C.R., Gallagher, V.J., Weldon, T.L. and Felder, R.M. 2000. 'Dynamics of Peer Education in Cooperative Learning Workgroups', Journal of Engineering Education, 89(3), pp. 285 - 293.

[9] Craig, K.J. and van Waveren, C.C. 1997. 'Simulating the engineering project environment using cooperative learning: a second-year course case study', International Journal of Mechanical Engineering Education, 25(4), pp. 291 - 297.

[10] Dunne, F.P.E. and Taylor, D.A.W. 1995. 'Engineering science-led computer-aided design: a project-based approach', International Journal of Mechanical Engineering Education, 23(3), pp. 181 - 193.

[11] Johnson, A.D. and Sherwin, K. 1993. 'A design-built-test project for first-year students', International Journal of Mechanical Engineering Education, 21(1), pp. 27 34.

[12] Kittleson, J. M. and Southerland, S.A. 2004. 'The Role of Discourse in Group Knowledge Construction: A Case Study of Engineering Students', Journal of Research in Science Teaching, 41(3), pp. 267 - 293.

[13] Wilkinson, I.A.G. and Fung, I.Y.Y. 2002. 'Small-group composition and peer effects', International Journal of Educational Research, 37, pp. 425 - 447.

[14] Slavin, R. E. 1995. Cooperative learning: Theory, research, and practice. Boston: Allyn \& Bacon.

[15] Lister, G. and Donaldson, K. 2004. 'New roles for Industrial Engineers in developing countries', South African Journal of Industrial Engineering, 15(1), pp. 43-52.

[16] Newport, C.L. and Elms, D.G. 1997. 'Effective Engineers', International Journal of Engineering Education, 13(5), pp. 325-332.

[17] Fertuck, L. 1995. Systems Analysis and Design with modern methods. Dubuque: Wm. C. Brown Communications Inc.

[18] Kendall, A.D., \& Kendall, J.E. 2002. Systems Analysis and Design, $5^{\text {th }}$ edition. New Jersey: Prentice Hall.

[19] Kaufman, D.B., Felder, R.M. and Fuller F. 2000. 'Accounting for Individual Effort in Cooperative Learning Teams', Journal of Engineering Education, 89(2), pp. 133 - 140.

[20] Middleton, H. 2002. 'Complex problem solving in a workplace setting', International Journal of Educational Research, 37(1), pp. 67 - 84. 
